\title{
Experience and sexuality education in creation of audiovisual installation
}

\author{
Experiência e educação sexualidade na criação de instalação audiovisual \\ Experiencia y educación en sexualidad en creación de instalación audiovisual
}

\begin{abstract}
Experience and education on sexuality is a unity of things / events experienced by individuals / groups regarding sex and sexuality which are then reduced to an informal educational structure. The purpose of this research is to explain the concept of artwork that underlies the creation of the audiovisual installation and the process of visualization of artwork on the creation of audiovisual installation. The media for creating works that are applied is an audiovisual installation art. Inspired by the previous works of Julian Rosefeldt (Manifesto), Gerda Wegener (Solitaire), Mella Jaarsma (Potong Waktu) and Halsey (Album Manic). The method of creation is based on Laura H. Chapman's theory with three stages, namely Inception of Idea, Elaboration and Refinement, and Execution in a Medium.
\end{abstract}

Keywords: Audiovisual; Installation; Sexuality.

\section{Resumo}

Experiência e educação sobre sexualidade é uma unidade de coisas / eventos vivenciados por indivíduos / grupos em relação ao sexo e sexualidade que são então reduzidos a uma estrutura educacional informal. O objetivo desta pesquisa é explicar o conceito de obra de arte que fundamenta a criação da instalação audiovisual e o processo de visualização da obra de arte na criação da instalação audiovisual. O meio de criação de obras aplicadas é uma instalação audiovisual. Inspirado nos trabalhos anteriores de Julian Rosefeldt (Manifesto), Gerda Wegener (Solitaire), Mella Jaarsma (Potong Waktu) e Halsey (Album Manic). O método de criação é baseado na teoria de Laura $\mathrm{H}$. Chapman com três estágios, a saber, Iniciação da Idéia, Elaboração e Refinamento e Execução em um Meio.

Palavras-chave: Audiovisual; Instalação; Sexualidade.

\section{Resumen}

La experiencia y la educación sobre la sexualidad es una unidad de cosas / eventos experimentados por individuos / grupos con respecto al sexo y la sexualidad que luego se reducen a una estructura educativa informal. El propósito de esta investigación es explicar el concepto de obra de arte que subyace en la creación de la instalación audiovisual y el proceso de visualización de la obra de arte en la creación de la instalación audiovisual. El medio de creación de obras que se aplica es un arte de instalación audiovisual. Inspirado en los trabajos anteriores de Julian Rosefeldt (Manifesto), Gerda Wegener (Solitario), Mella Jaarsma (Potong Waktu) y Halsey (Album Manic). El método de creación se basa en la teoría de Laura H. Chapman con tres etapas, a saber, Inicio de la idea, Elaboración y perfeccionamiento y Ejecución en un medio.

Palabras clave: Audiovisual; Instalación; Sexualidad.

\section{Introduction}

Humans and sexuality are inseparable unity. Sexuality is formed from understanding sex and sexuality. According to the Indonesia AIDS Coalition, sex is a biological form that differentiates men and women. Meanwhile, sexual activity is sex that involves both physical and non-physical organs. two types of combined definitions will form the word sexuality, within the analysis related to sex and sexuality based on biological, social, political and cultural factors of individuals. International Technical Guidance on Sexuality Education of UNESCO (2018) outlining the factors which stated about how a person lives in a world, where psychological and physical health is threatened by HIV and AIDS, pregnancy by accident, gender-based violence (GBV) and gender inequality still cause a serious threat to people health.

If the sexuality understanding of society (especially for children) still low, thus, it can lead to wrong perspectives and impact on negative aspect that causes immoral behavior (Damayanti et al., 2018) This statement considered as true and can be 
occurs in human life. As the existence of gender domination, patriarchy and matriarchy cases, which always exist in every level of society, Rape cases which happen every day took 8 victims based on the Komnas Perempuan survey (2019), illegal abortion that never received a win-win solution and the intimidation of LGBTQ+ society in Indonesia.

The cases that appear are predicted to occur because of the low interest of community to undergo the literation of sexual education. The Program for International Student Assessment (Schleicher, 2015) stated that Indonesia's literacy interest is ranked 62 th out of 70 countries.

Based on the problem of understanding sexuality education which is less comprehensive and the lack of interest in literacy, formed an idea of artworks creation. The idea is designed to convey sexuality education based on personal experiences and closest colleagues through creative media in form of artworks. The experiences taken from the experiences that represent branches of discussion on sexual education such as illegal abortion and LGBTQ+ gender spectrum. There is a selection of work media in form of audiovisual installations (McConchie \& Rolfe, 2016).

In their duty, the artist is always affected by it surrounding environment, whether the environment as source of inspiration, object of work, and the environment as connoisseur (Ferriani, 2013). There is a process of studying / observing the concepts and works of previous artists. It was done to enrich visual references and ideas of work. Previous artworks that influenced the current creation included Julian Rosefeldt (Manifesto), Gerda Wegener (Solitaire), Mella Jaarsma (Cut Time) and Halsey (Album Manic).

Julian Rosefeldt's artwork (Manifesto) consists of 13 film channels which referred as film installations. The use of film channels with audio and visual compositions is inspiring to adapt them for an audiovisual installations. Then, the work of Gerda Wegener (Solitaire) depicts the first transgender figure in the world, Lili Elbe, her ex-husband. Wegener's discussion of sexual orientation / gender spectrum inspire other ideas about sexuality. There are also Halsey's work (Album Manic) which tells the story of his sexuality journey as bisexual until he diagnosed with bipolar. Halsey's music (audio) and drawing stop motion (visuals) are very personal and make his fans feel that they have experienced what Halsey has experienced. The final inspirational work is Mella Jaarsma's (Cut Time). It is rare to see humans as objects of installation, Jaarsma's art installations present humans as objects of composing the unity of his work. The presence of humans as objects to supports the topic of sexuality discussion which can not be separated from human existence. The four artists with their previous works influenced the creation of this current work. The difference in creation is the concept that underlies each work.

Based on the explanation above, research problem can be formulated as below:

1. What is the concept of artwork that underlies the creation of the audiovisual installation?

2. How is the visualization of artwork on the creation of audiovisual installation?

\section{Methodology}

The creation method used used in this creation was done based on the theory Laura H. Chapman. Chapman is an art education critic from Cincinnati, Ohio. Chapman has experience of teaching an art at Indiana University, Ohio State University, University of Illinois and University of Cincinnati. Chapman book entitled Approaches In Art Education (Chapman, 1978) explained that there are three stages of art creation. The first stage called as the Inception of Idea, it is where the creator of artwork determines the object, direction and purpose of which the artwork was created. Elaboration and Refinement is a process of processing and refining ideas that carried out to obtain more systematic and structured visual study (Richardson et al., 2013). Execution in a Medium is the proficiency of selecting and applying the selected media.

Generally, Inception of Idea is the process of creating the idea (Bressler, 2011). It begin from obtaining a background that contains a problem or thing that need to be expressed through a artwork. In this case, the background of creation was 
based on personal experiences and the closest people that related to sexuality. There is an intended experiences which have the detailed discussion object related to the dominance of gender patriarchy and matriarchy that experienced by A, rape criminal case that happen to little girl in Karanganyar on 2016, an illegal abortion which a colleague with initials G is an LGBTQ+ gender spectrum that occurred in a group in Malang. The object of discussion has been experienced to become an artwork. The aim and goal is to achieve mental broadness and educate the public through the experience of sexuality as embodied in works of art. The following below is a "concept" document of the Inception of Idea process:

Figure 1. The process of Inception of Idea related to the object of discussion of matriarchy and patriarchy gender domination.

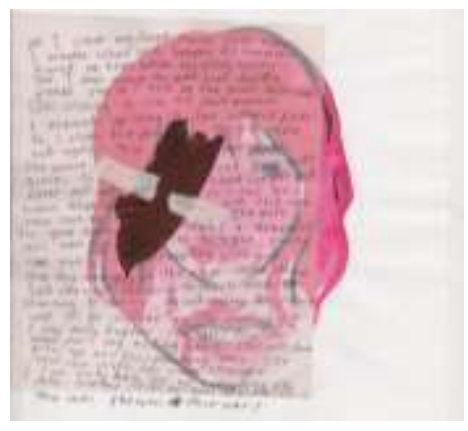

Source: Author.

Figure 2. The process Inception of Idea related to the discussion of rape.

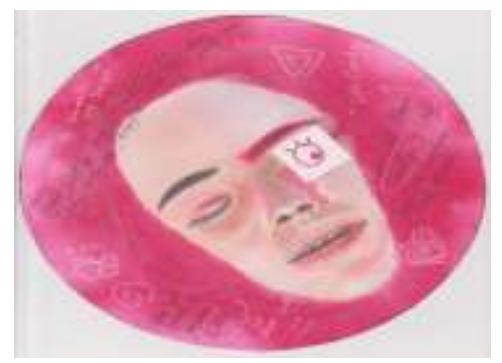

Source: Author.

Figure 3. The process Inception of Idea related to the discussion of abortion.

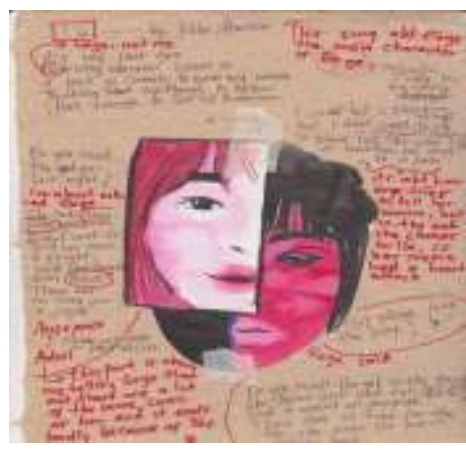

Source: Author. 
Research, Society and Development, v. 10, n. 6, e39610615627, 2021

(CC BY 4.0) | ISSN 2525-3409 | DOI: http://dx.doi.org/10.33448/rsd-v10i6.15627

Figure 4. The process Inception of Idea 1 related to the spectrum gender of LGBTQ+.

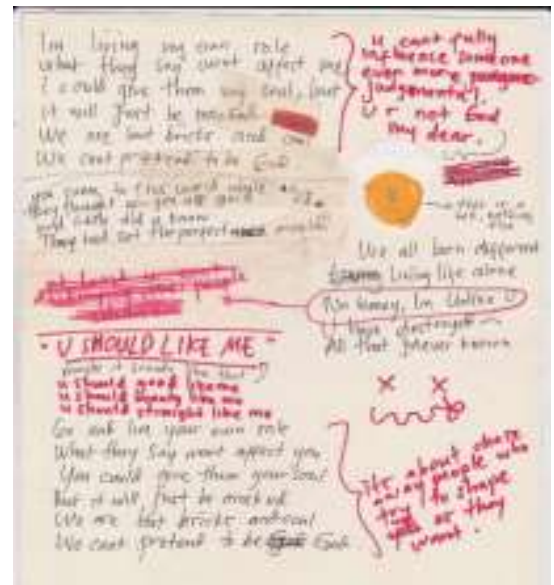

Source: Author.

Figure 5. The process of Inception of Idea 2 related to the gender spectrum of LGBTQ+.

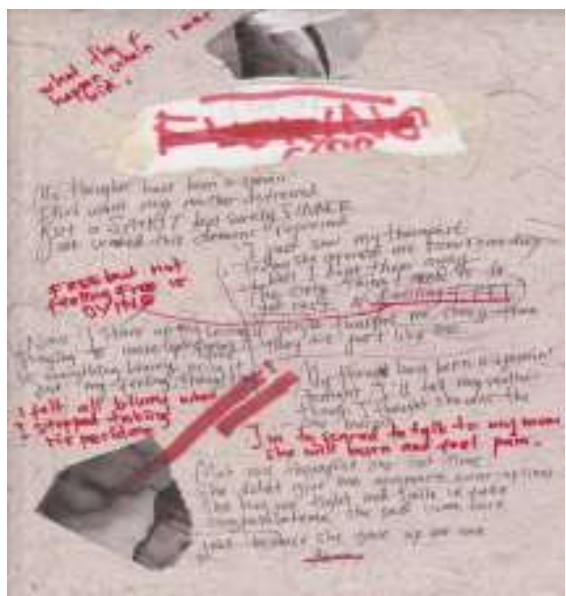

Source: Author.

Figure 6. The process of Inception of Idea 3 related to the gender spectrum of LGBTQ+

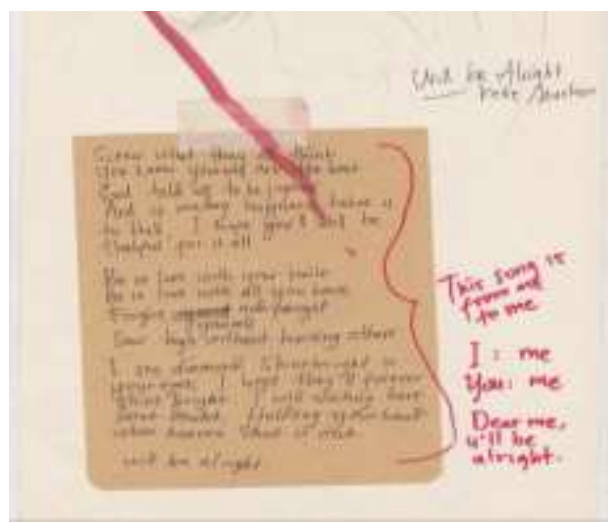

Source: Author. 
Beside being a basis of visual works, the results of Inception of Idea will be given to studio partner Ardiand Production to be processed into audio music. After obtaining the object, direction and purpose of creating an artwork through Inception of Idea, the next step is Elaboration and Refinement. In this process, the results of the Inception of Idea are elaborated into an enhanced visual sketch.

The object of discussion on the gender domination of matriarchy and patriarchy if it being manifested in a sketch will visualize the characters of R. A. Kartini and Mary Wollstonecraft. Those two figures are the fighters of gender equality in Indonesia and world. There are supporting visualization in form of tarot cards symbolize a victory (over gender equality).

Figure 7. Sketches with the object of discussion matriarchy and patriarchy gender domination.

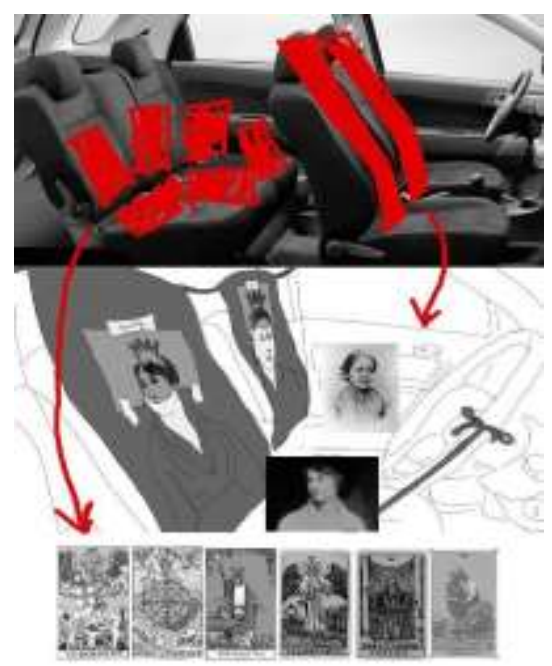

Source: Author.

The object of rape discussion, if embodied in sketch, will visualize a female character in children's costumes and dolls. This is because the experience was taken based on the case of children rape of on 2017 in Karanganyar. The supporting visualization is a metaphor of a vaginal shape with a woman's face.

Figure 8. The sketch with the object discussion of rape.

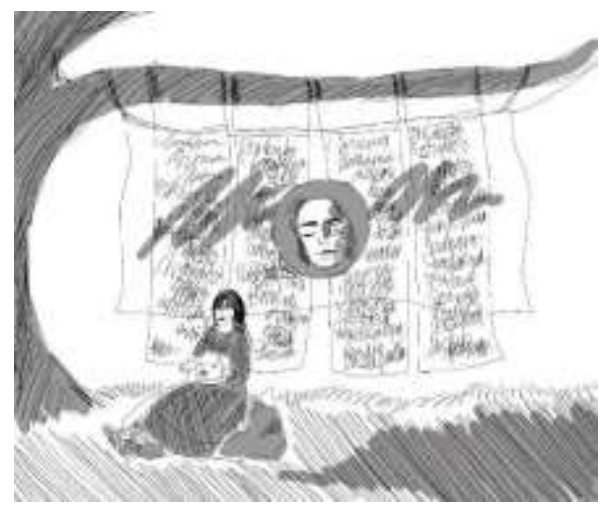

Source: Author. 
if the object of discussion of abortion, embodied in a sketch, it visualize a bed and piano which is a black and white metaphor for someone's journey. Black and white are taken from how the piano notes work with different types of notes but complement each other. Most of people usually pay attention on the "black" side and they forget the "white" side. In fact, there are many reasons and perspectives that underlie abortion. The process of abortion taken from the perspective of women named G. her story summarized in stop motion as metaphor of her journey of life.

Figure 9. The sketches with the object discussion of abortion.

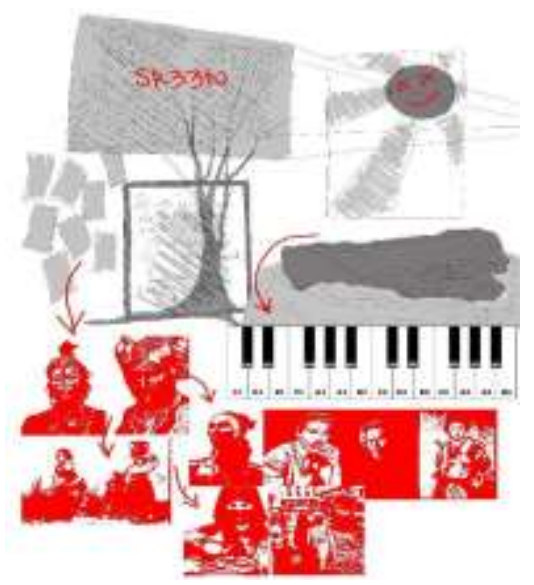

Source: Author.

The final object of discussion is experiences related to the LGBTQ + gender spectrum, If embodied in a sketch, it will visualize Queer and Transgender characters because both are most easily identified as a part of LGBTQ+ through their visual form, unicorns and rainbows as typical LGBTQ + icons and mythological figures Eros and Psyche as metaphors of pure love.

Figure 10. Sketch 1 within the object of LGBTQ+.

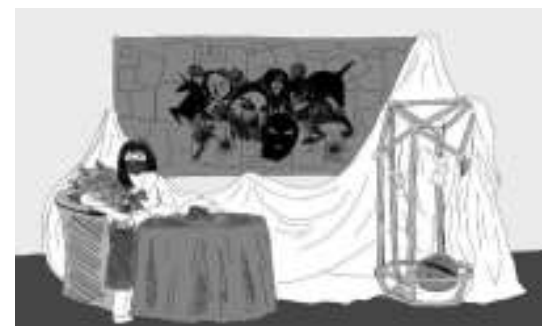

Source: Author.

Figure 11. Sketch 3 within the object of LGBTQ+.

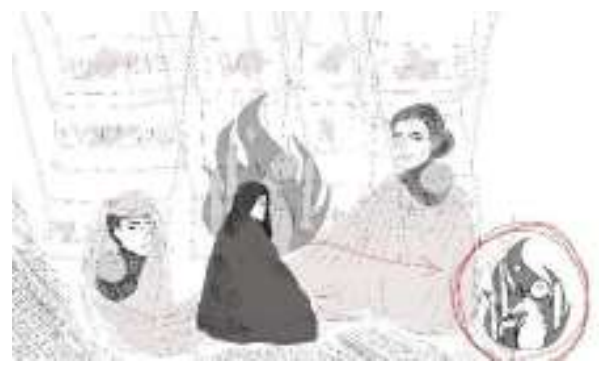

Source: Author. 
Figure 12. Sketch 2 within the object of LGBTQ+.

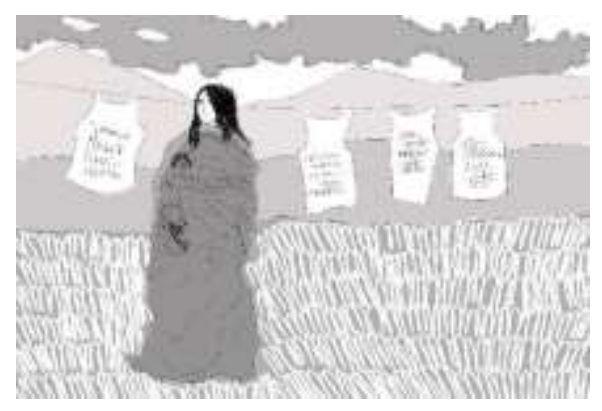

Source: Author.

The last stage is Execution in a Medium. To achieve this process, it requires knowledge materials of the media. The materials used are quite diverse, ranging from textiles, wood, glass, resins and acrylics. The material is selected as the basis history of creation from the previous work thus, it is able to facilitate the process. Beside the mentioned material above, there are also digital media such as videos / films that presented through projectors and speakers. When every material was gathered, it will form a work media of an audiovisual installation. It is called an audiovisual installation because there is an installation more than one object in a unified work, these objects are formed from something that can be seen and heard therefore it is declared as an audiovisual properties. The following below are the results of Execution in a Medium.

Figure 13. The Execution in a Medium with the object discussion of matriarchy and patriarchy gender domination.

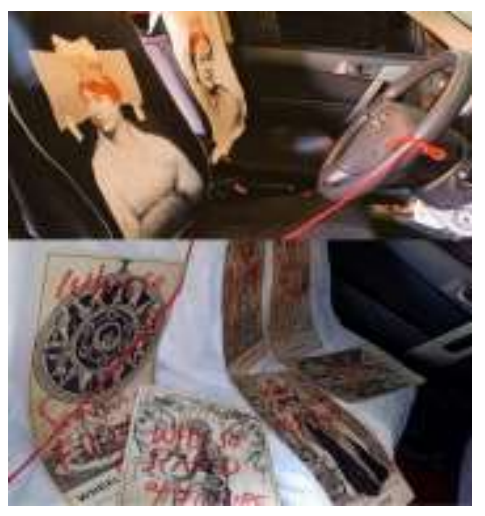

Source: Author.

Figure 14. The Execution in a Medium with the object of rape.

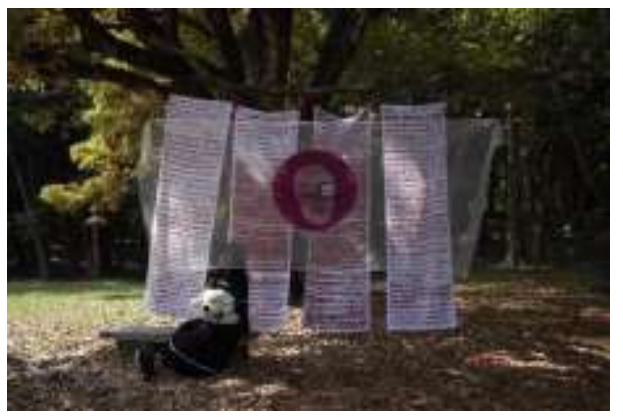

Source: Author 
Research, Society and Development, v. 10, n. 6, e39610615627, 2021

(CC BY 4.0) | ISSN 2525-3409 | DOI: http://dx.doi.org/10.33448/rsd-v10i6.15627

Figure 15. The Execution in a Medium with the object of abortion.

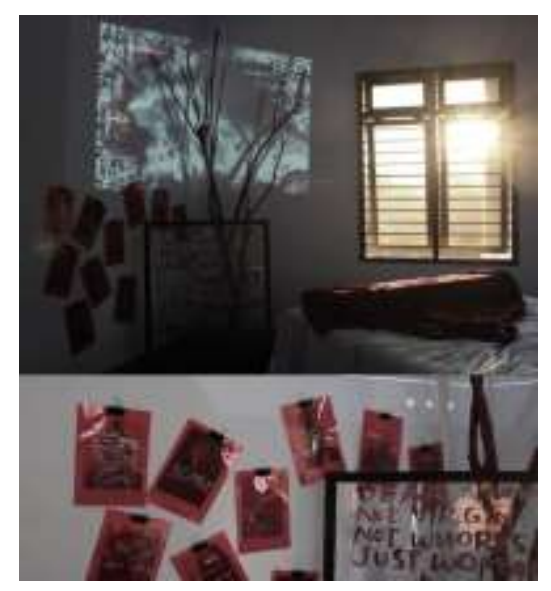

Source: Author.

Figure 16. The Execution in a Medium 3 within the discussion of LGBTQ+.

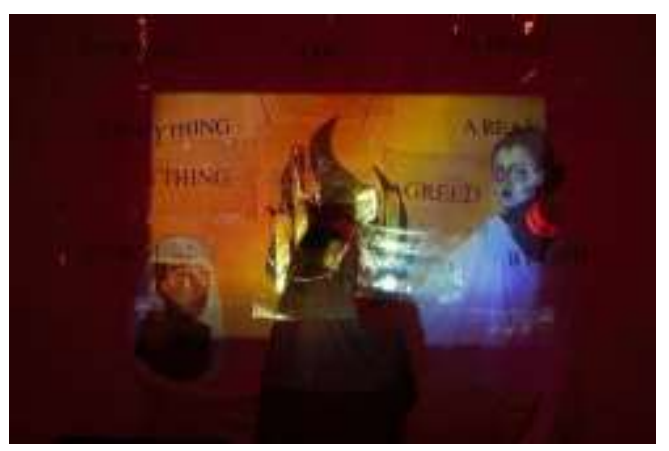

Source: Author.

Figure 17. The Execution in a Medium 1 within the discussion of LGBTQ+.

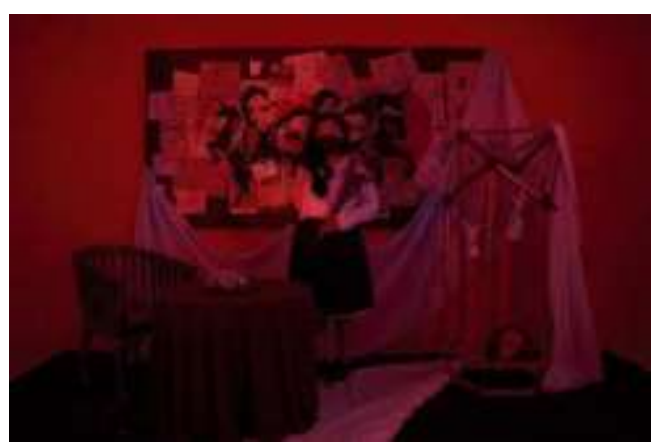

Source: Author. 
Figure 18. The Execution in a Medium 2 within the discussion of LGBTQ+.

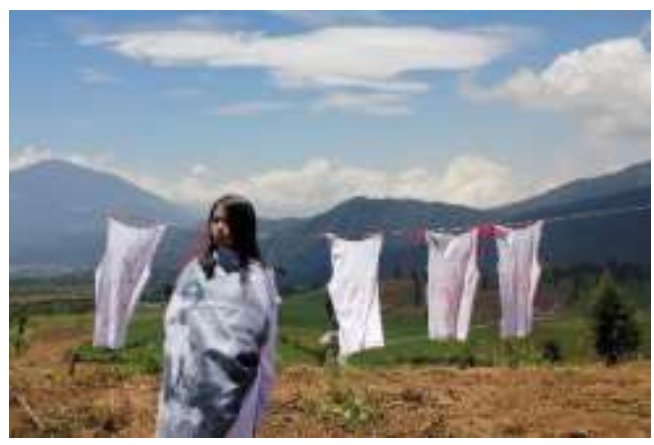

Source: Author.

\section{Result}

The result aimed at this creation is the concept and visualization of audiovisual installation. After going through the method of creation, Laura H. Chapman finally formulated 6 concepts with 6 different visualizations. These concepts are derived from the objects of discussion formulated at the three stages of Laura H. Chapman's

The concept of the first artwork communicates the ideas of gender inequality experiences that occur as a result of strong misogyny mindset in neighborhood. Based on the social system in her neighborhood, women named A often gets prohibited from doing male tasks such as driving a car. A thought that something should be done by anyone who mastered it regardless the gender. This experience also felt by gender equality figures, namely R. A. Kartini and Mary Wollstonecraft. Visual objects in artworks that appear are the paintings of R. A. Kartini, Mary Wollstonecraft and tarot cards. These visual ideas and objects are executed in an audiovisual installation made from predominantly textiles. The first idea create an artwork entitled "Toasting with God". Toast with God interpreted as pure victory out of kindness and love. The struggle of R. A Kartini and Mary Wollstonecraft basically a struggle of kindness and love for those who are oppressed by patriarchy and matriarchy. The following below is the visualization of an audiovisual installation entitled Toasting with God. scan the barcode below for the best visualization.

Figure 19. Barcode scan visualization of audiovisual installation entitled Toasting with God.

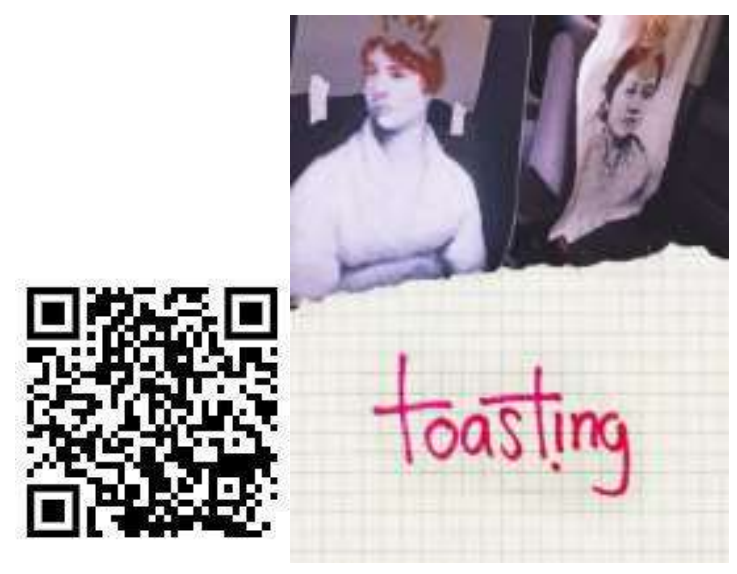

Source: Author.

Not only taken from one perspective of victim but also from the perpetrator who has mental disorder (pedophilia). The Visual objects in related artworks are metaphors of rape victims in form of women in children's costumes and dolls plus a 
metaphor of the shape of vagina. These visual ideas and objects are executed in audiovisual installation made from predominantly textiles. The idea for the second artwork obtain an artwork entitled "No Wish to Save Us?". Basically, the creation of second artwork focuses on rape which often lead to judgment rather than salvation (Finley, 2018). The following below is the visualization of audiovisual installation entitled No Wish to Save Us. scan the barcode below for the best visualization

Figure 20. Scan Barcode of the visualization of No Wish to Save Us.

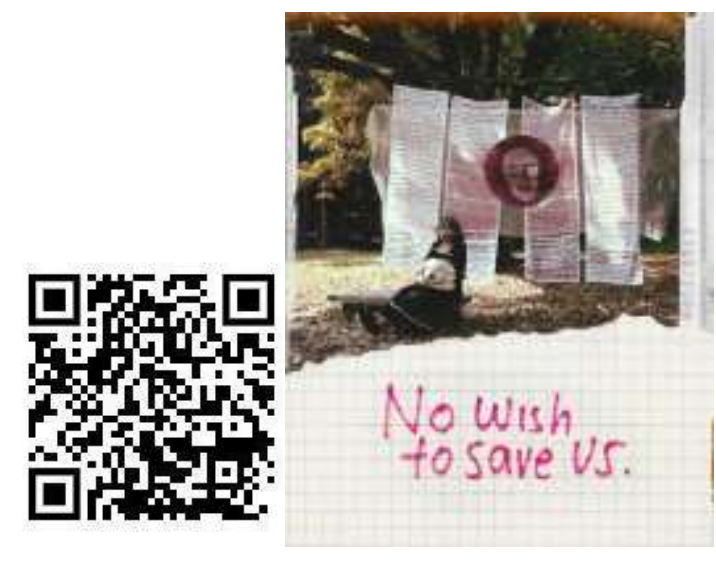

Source: Author.

The third concept communicated the idea of abortion from the perspective of women named G. The abortion experience is different from most cases because the perspectives did not blame the abortionist (negatively). The abortion experience is also adjusted to the WHO record about abortion. Visual objects in artworks that appear are bed and piano, a picture of a world figure who has experienced abortion that was involved in it and a stop motion that contains a metaphor for G's journey of life. These visual ideas and objects are then executed in an audiovisual installation made from textiles, wood, glass and video projectors. The idea of the third work provide to an art work entitled "Lie". The following below is the visualization of an audiovisual installation work entitled Lie. scan the barcode below for the best visualization.

Figure 21. Scan Barcode visualization of lie.

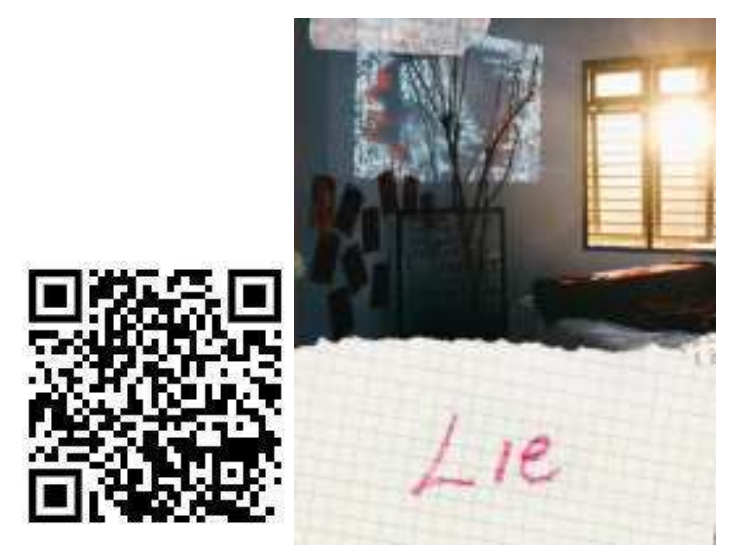

Source: Author. 
The fourth, fifth and sixth concepts of artworks communicate ideas regarding the issues on the LGBTQ + gender spectrum. The fourth artwork is about the experience of the injustice of LGBTQ+ rights around the artist's environment. The experience was taken from the point of view of two kind of groups Queer and Transgender (Jackson, 2010). The visual object that occur is the character of Queer and Transgender, within the headline of "Everyone has a choice, everything has a reason and everything has agreed by God", sleeping performers in red cloth, a metaphor of a unicorn, and rainbow. These visual ideas and objects then executed in an audiovisual installation made of textiles, wood, plastic and video projectors. The fourth idea obtain an artwork entitled "To be God". Being God interpreted as anti-LGBTQ+ behavior that is often judgmental and seems to act as a God. The following below is the visualization of an audiovisual installation entitled To be God. Scan the barcode below for the best visualization.

Figure 22. Scan Barcode visualization of To be God.

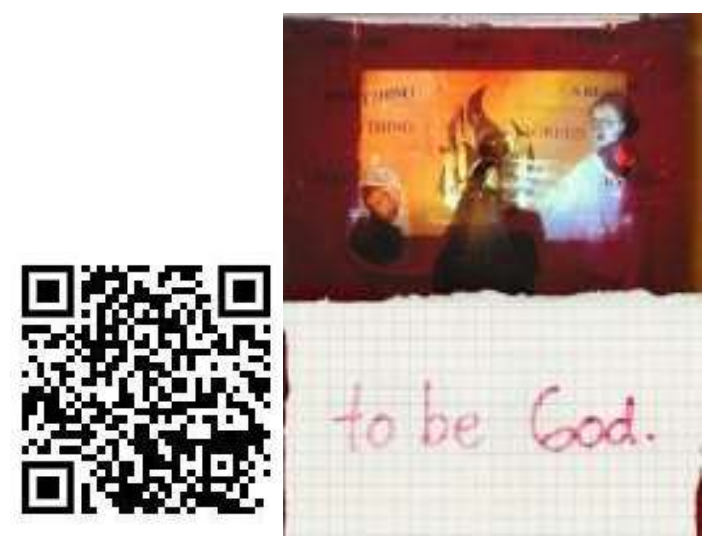

Source: Author.

The fifth work conveys the idea of less literacy on sexual education in schools, resulting in unfavorable risks. These risks are depicted through the blackboard object with a black unicorn icon that symbolizes negative behavior of LGBTQ+ groups, a veiled figure as a symbol of cross-hijabers case that went viral in 2019 and a masked figure which has meaning a movement of rebellion. These visual ideas and objects are executed in an audiovisual installation made from textiles, wood, plastic and video projectors. The fifth idea obtain an artworks entitled "To be Human". Being human in the fifth concept is interpreted as form of fulfilling the human right to learn and know regarding the sexuality. The following below is the visualization of the audiovisual installation entitled To be Human. The barcode below will be directed to the visualization of to be human. 
Figure 23. Scan Barcode visualization of to be human.

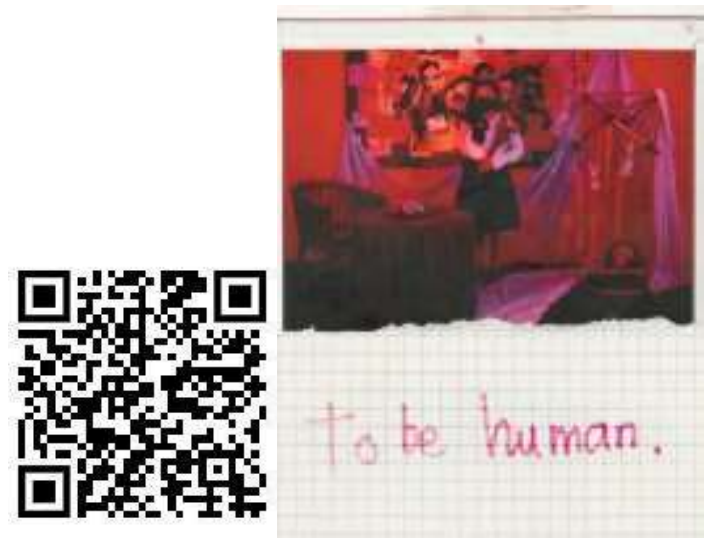

Source: Author.

The sixth artwork conveys the idea of self-acceptance related to sexuality. there are some people who do not accept the fluctuation of different sexuality in, therefore it is difficult to feel happy and live within the expectation of other people. This case was taken from the experience of a person who just realized that he was a homosexual after 35 years of life. The visual objects of works that appear are clothes hanging from a height and the character of Eros - Psyche. These visual ideas and objects are executed in an audiovisual installation made from predominantly textiles. The sixth idea of an artwork obtain an artwork entitled "Will be Alright". The title comes from the concept of "clothes reflect the inner person". Based on the concept, quotes are applied for the clothes. The quotes can be motivation and self love. The following below is the visualization of audiovisual installation entitled will be alright. The barcode below will be directed to the visualization of will be alright.

Figure 24. Scan Barcode visualization of will be alright.

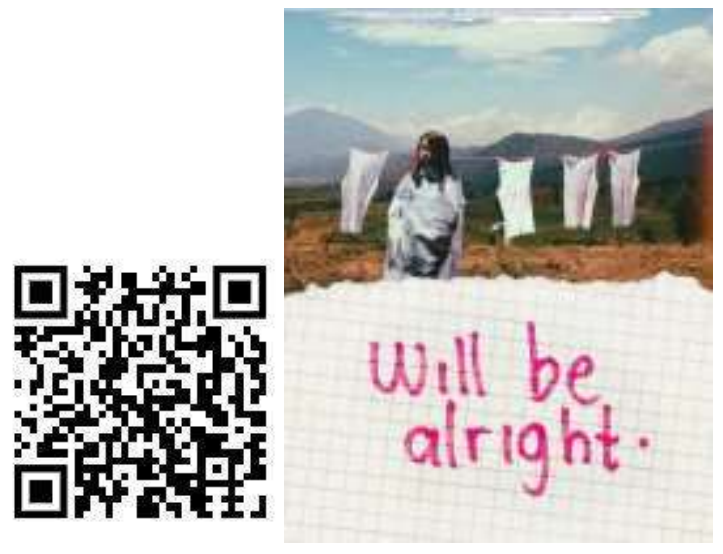

Source: Author.

In the current creation, each work influences other. An artwork with the idea of LGBTQ + provide other ideas of sexuality. The first work that was created entitled "To be Human" with a concept of sexuality education which is in reality difficult to mingle in society and it causes a deviant characteristic of human. Based on those idea, it cames an idea of work entitled "To be God" which complements the previous work. The deviant nature of an artwork "To be Human" which cause a judgement of public response. Judgment is closely related to the nature of God, this opinion influenced by the phrase of "Only 
God can judge me ..." by Tupac Shakur, a rapper, actor, activist and poet from US. an artwork entitled "To be God" basically is a satire of people who like to judge any deviant characteristic without any knowledge and understand of what happen behind the reality through education. Then, an art work entitled "To be God" influenced the creation of a work entitled "Lie" considering the judgment received by an informant with intial $\mathrm{G}$ a victim of rape and was forced to have an abortion for his mental health. The Judgment received by G several times led to gender discrimination. It inspired the creation of a work entitled "Toasting with God" which was previously given the title "Toasting". The work has the idea of human victory if it succeeds in living with human equality. The equality should be applied to every levels of society regardless of 'black' or 'white', it has inspired the creation of artwork entitled "No Wish to Save Us" which tells the case of rape within the indications of pedophilia from two perspectives of perpetrators and victims. In this case, based on personal point of view, the one who should receive help is not only the victim but also the perpetrator who was born and experienced a deviant sexuality. every chaos in the idea of work has inspired the creation of an artwork entitled "Will be Alright" which basically a self-acceptance of everything, especially sexuality. After every ideas being formulated, artwork creation sequence was formed based on the smallest ideas to the most challenged idea.

In terms of ideas and choosing visual forms of works that influence each other, Apart from being influenced by previous works, visual forms are influenced by the edition of created work. an artwork entitled "To be Human" influenced the visualization of"To be God" and "Lie" while "No Wish to Save Us" influenced by the visual of "Toasting with God" and "Will be Alright". Within the further observation, the works entitled "To be Human", "To be God" and "Lie" take an advantages from the items with higher volume, digital media, and complex objects. Meanwhile, the works entitled "No Wish to Save Us", "Toasting with God" and "Will be Alright" consist of fabrics that simply displayed outdoors and tend to take an advantages from artificial objects that are not really complex. The complexity of an artwork "Wish to Save Us", "Toasting with God" and "Will be Alright" are provided inside the natural objects which support the establishment of installation. If being observed in more detailed idea, the materials used are related to each other. This is happen due to the habit of the creation process before the idea of sexuality and education was published. Tendency to choose textiles, wood, plastic, glass, etc. is already attached and becomes idealistic for the present and further creation.

\section{Discussion}

The Discussion analysis is discussed holistically both in terms of theory, previous work and what is found in the process of its creation.

\section{Theoretical Analysis}

Quoted from cambridge dictionary (2020) "experience is (the process of getting) knowledge or skill from doing, seeing, or feeling things" experience refers to knowledge and skills regarding something that obtained through involvement or related to something during certain period.

Meanwhile, according to Berger (2019) sexual education is a series of education that aims to develop and strengthen the ability of children and adolescents to make conscious, satisfying, healthy and respectful choices about emotional and physical sexuality. Based on International technical guidance on sexuality education: An evidence-informed approach (2018) by UNESCO, sexuallity is the way humans experience and express themselves sexually. It involves biological, erotic, physical, emotional, social, or spiritual feelings and behavior. Better Health Channel (2020) lists sexuality as feelings, thoughts, interests and sexual behavior towards other people physically and emotionally.

Based on the two theories above, sexuality experience and education are unitary concept in form of a series of sexual education that experienced directly in certain period. Simply, the experience contained in concept is the experience of 
sexuality which taken as material for informal educational ideas about sexuality. The concept is packaged in the creation of audiovisual installation works of art.

The term installation is used to describe large-scale of mixed media construction. It is often designed for specific place or specific period of time. Installation art often occupies the entire space that appreciator passes in order to fully involved with the presented artwork (ART TERM, 2020). Several installations only designed for walking around and can only be seen from the end of the room because it is very fragile (Schleicher, 2015). What makes installation art different from sculpture or other traditional art is the unified and complete object rather than separate display of individual artwork. Ilya Kabakov on the TATE Gallery website states that "The main actor of total installation, the main center toward which everything is addressed, which everything is intended, is the viewer"

If defined simultaneously, audiovisual installation is a complex, large-scale media construction that can be heard and seen. The audiovisual installation is a forum of work with the concept of experience and sexual education (Policy Brief, 2016). The choice of audiovisual installation was based on the number of objects that need to be combined, personal interest and the trend of art installations in the last decade. It can be seen by the number of paid exhibition like Haluu World. It is expected to gain more interest from people.

Based on the disseminated theory above. every works have fulfilled the core points in creating audiovisual installations within the concept of sexual experience and education. The points include: 1) the artworks based on experiences of sexuality that have been experienced, 2) obtaining an informal sexuality education design, 3) art installations as a media of creating an artworks 4) types of installations can be seen and heard.

The artwork entitled "Toasting with God" has a concept of gender inequality, matriarchy and patriarchy. Matriarchy is social system which mother or female elder has absolute authority over a group of family (Schiavoni, 2016) Women are the main part of patriarchal culture, as happened to Minangkabau ethnic in West Sumatra. It is different with Patriarchy which has the opposite of Matriarchy. Patriarchy is a system of mental, social, spiritual, economic and political organization/social structure that relies on men. The institutions are connected to each other not only to strengthen the structures of male domination over women, but also with other systems of exclusion, oppression and / or domination based on real or perceived differences between humans. (Storkey, 2020)

Both matriarchy and patriarchy have negative and positive impacts related to their respective portions. The emergence of an domination provide boundaries that reluctant to be violated by male and female. For example, in patriarchal culture (certain societies), women's gender (having boundaries) is prohibited from being a leader and considered a kitchen "property". The concept of limitation becomes a culture that absorbed by local society. There are still minimum understanding of gender equality in local culture.

Gender inequality: matriarchy and patriarchy are derived topics of sexuality. this education comes from the experience of a women regarding misogyny system that is mixed with the concept of patriarchy. misogyny is a form of women discrimination (Code, 2000).

Based on the idea of the concept, the artwork entitled "Toasting with God" has fulfilled points 1 and 2 regarding the experience of sexuality education design. Gender inequality is a part of sexual education of UNESCO's theory in International Technical Guidance on Sexuality Education. UNESCO claims a topic can be classified as sexual education when it can give a sense of freedom to express a topic sexually. 
Figure 25. The objects of composing artwork by the characters R. A. Kartini and Mary Wollstonecraft

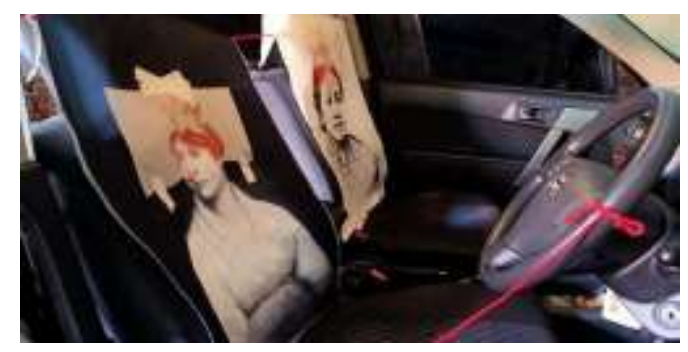

Source: Author.

Figure 26. The object of composing artwork by Tarot card.

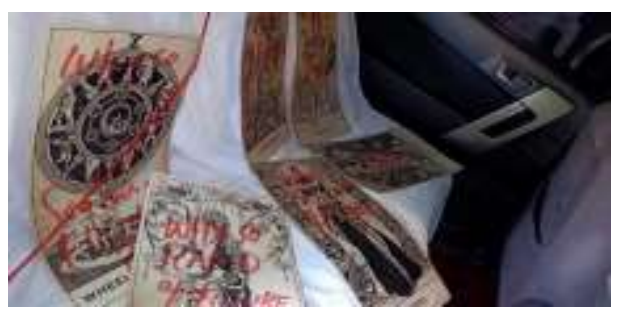

Source: Author.

The second work entitled "No Wish to Save Us" has the concept of a rape case. Rape is sexual act relations with someone without their consent, through violence or threats of violence (Ubell \& Randall, 2018).

This case happened to a little girl in Karanganyar 2017. Although this case is classified as rape, there are indications of cases of pedophilia in it. The perpetrator is suspected of being pedophile and has carried out his actions on 16 underage boys. Pedophilia is a mental illness in adults (over the age of 18 years) who have sexual attraction to children who is 12 years younger than he, Encyclopedia Britannica (2017) is.

Based on the idea of the concept, the artwork entitled "No Wish to Save Us" has fulfilled points 1 and 2 regarding experience as a sexuality education design. The experience is taken from the story of a rape victim in Karanganyar. The medium used also fulfilled the requirements of points 3 and 4 regarding the theory of audiovisual installations. It is characterized by the existence of large-scale and complex mixed media constructions which can be seen and heard. mixed media are the composing objects and supporting audio. 
Figure 27. The object of composing artwork by sexuality experience record panel.

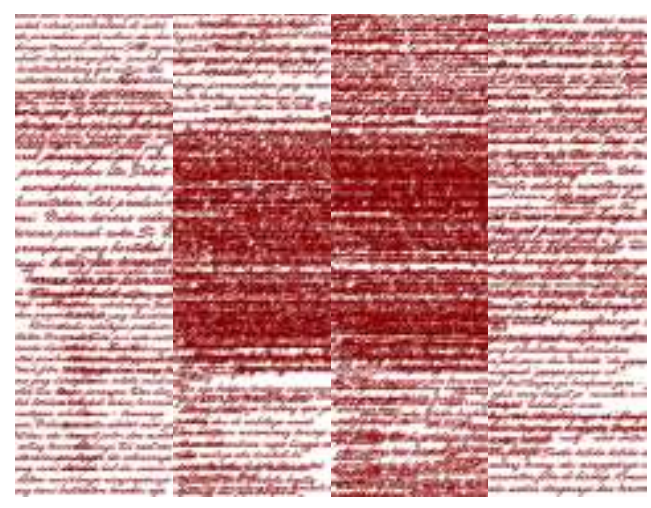

Source: Author.

Figure 28. The object of composing artwork by little girl costume.

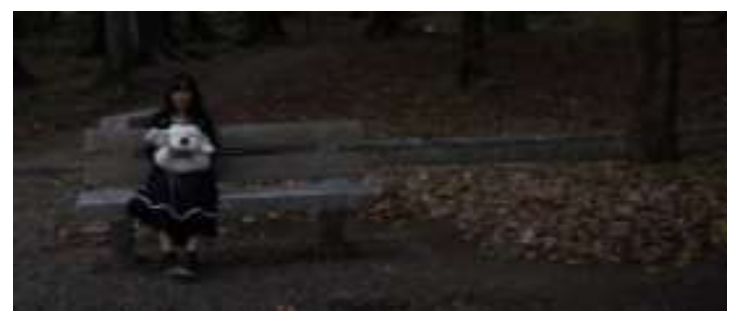

Source: Author.

Figure 29. the object of audio.

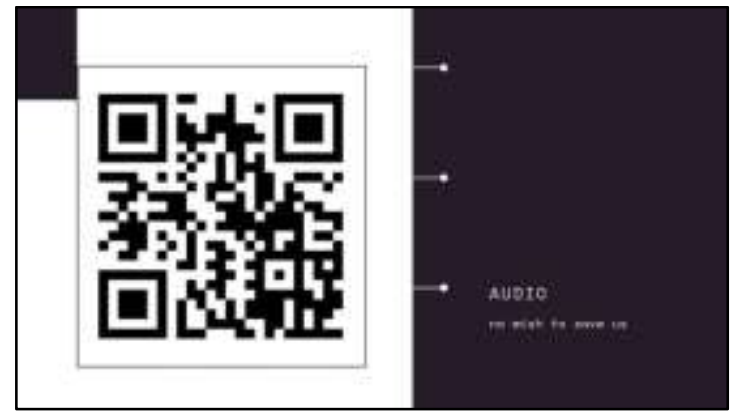

Source: Author.

The third work entitled "Lie" has a concept about abortion. According to Harvard Health Publishing (2019) abortion is the removal of pregnancy, products of conception or the fetus and placenta from uterus. Abortion is most often way that used to end an unplanned pregnancy.

The Abortion in Indonesia strictly regulated in constitution Article 75 paragraph (1) of Law no. 36/2009 concerning on Health. The impact is that victims who experience unplanned pregnancies (especially due to rape) are forced to have illegal abortions due to the regulations of the laws. The occurrence of illegal abortion attempts means that the government's has an efforts to prevent abortion through the law, however it still ineffective and not based on public agreement. The experience of sexuality in the form of abortion was experienced by women with the initials $G$ in 2017 . G is a victim of rape. After realizing that she was pregnant, $\mathrm{G}$ decided to have an abortion. However, due to the difficult and complicated legal abortion procedure, $\mathrm{G}$ thought about having an illegal abortion. 
Based on the idea on the concept, the artwork entitled "Lie" has fulfilled points 1 and 2 regarding experience as a sexual education design. Abortion can be included as material part of sexual education considering the idea to criticize the prosecution of sexuality issues. The medium that used meets points 3 and 4 regarding the theory of audiovisual installation. It is characterized by the existence of large-scale and complex mixed media constructions which can be seen and heard.

Figure 30. The objects of figures who have been involved in the abortion process, glass with the writing on the theme of abortion and dry trees.

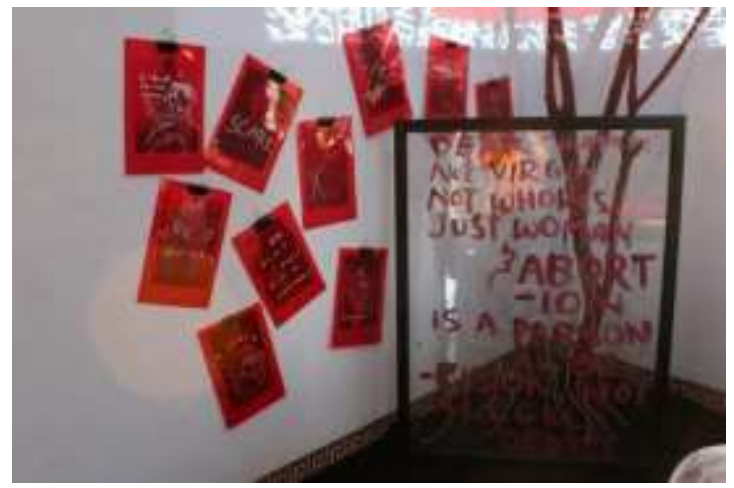

Source: Author.

Figure 31. The object of art creation by piano.

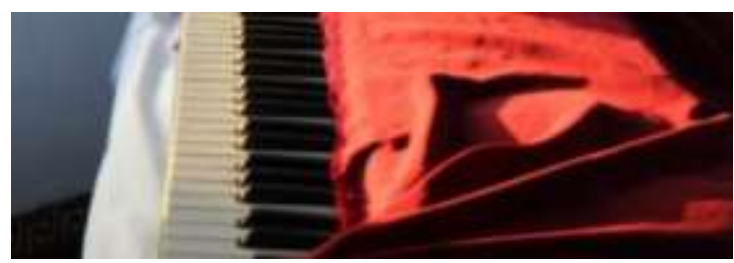

Source: Author.

Figure 32. The object of stop motion.

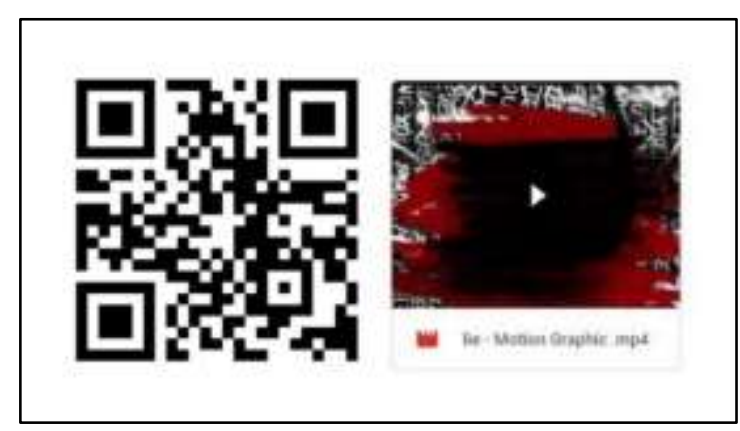

Source: Author. 
Figure 33. The object of audio.

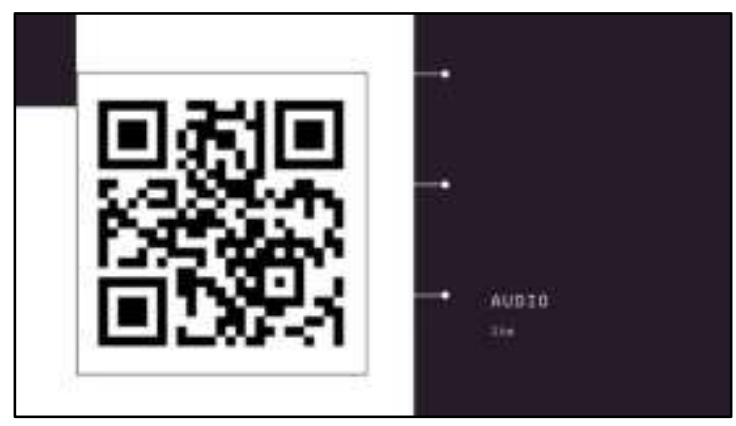

Source: Author.

The next artwork entitled "To be God", "To be Human", "Will be Alright" has a concept about the gender spectrum or LGBTQ+ sexual orientation. The gender spectrum is development of two genders for men and women.

As what stated from the journal by Diana-Abasi Ibanga (Eyo \& Ibanga, 2017) which claims that LGBTQ+ is innate homoeroticism in human sexuality that happen since birth. Homoeroticism is defined as same-gender attraction between men and men or women with women. it can be concluded that LGBTQ+ is natural variation in form of an irrevocable gender spectrum.

Although there are many studies that say LGBTQ+ is scientific human phenomena, there are also many rejections from other societies in Indonesia and the world. Rejection of LGBTQ+ is often based on the interests of religious communities and individual / group idealism,

Based on the idea of concept, the works entitled "To be God", "To be Human", "Will be Alright" have fulfilled points 1 and 2 regarding experience as a sexual education. The experience was taken from the story of LGBTQ+ communitty in Malang and its surroundings. UNESCO claims something can be classified as sexual education when it can provide a sense of freedom to express oneself sexual orientation. Meanwhile, the topic of LGBTQ + criticizes the right to choose sexual orientation. The medium that used also meets points 3 and 4 regarding the theory of audiovisual installations. It is characterized by the existence of large-scale and complex media constructions which can be seen and heard.

Figure 34. The object of Queer, Transgender dan Unicorn characters.

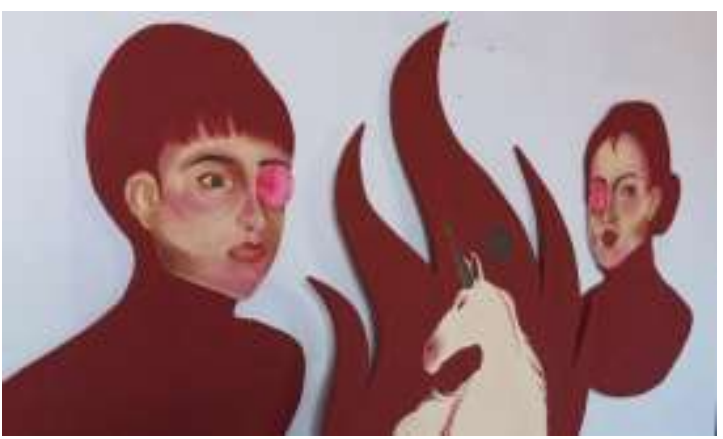

Source: Author. 
Research, Society and Development, v. 10, n. 6, e39610615627, 2021

(CC BY 4.0) | ISSN 2525-3409 | DOI: http://dx.doi.org/10.33448/rsd-v10i6.15627

Figure 35. The construction object the symbolize by rainbow.

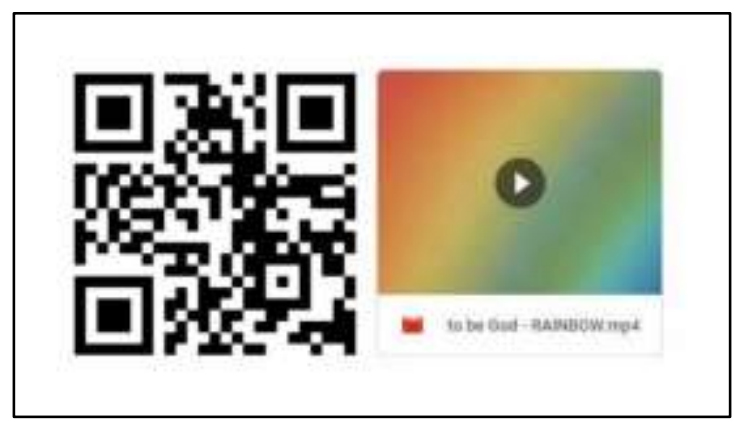

Source: Author.

Figure 36. Construction of every object.

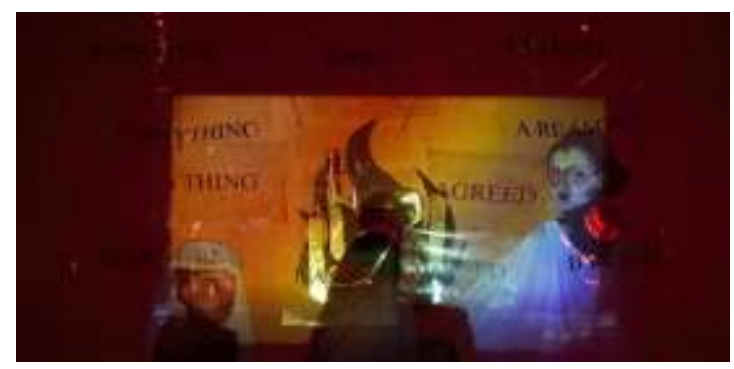

Source: Author.

Figure 37. The object of sexuallity icon.

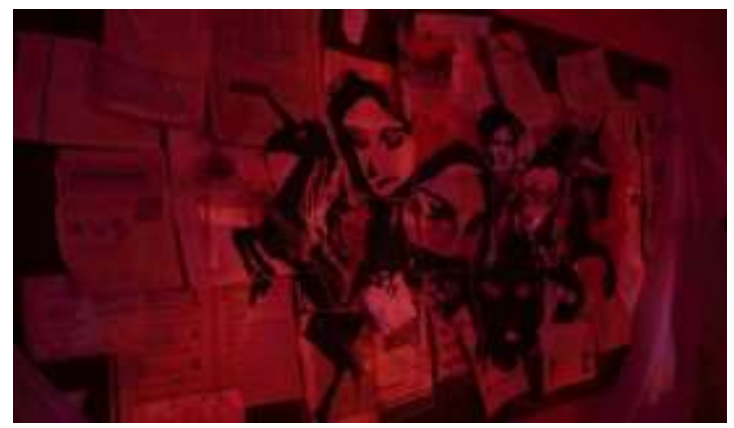

Source: Author. 
Figure 38. The construction object of clothes.
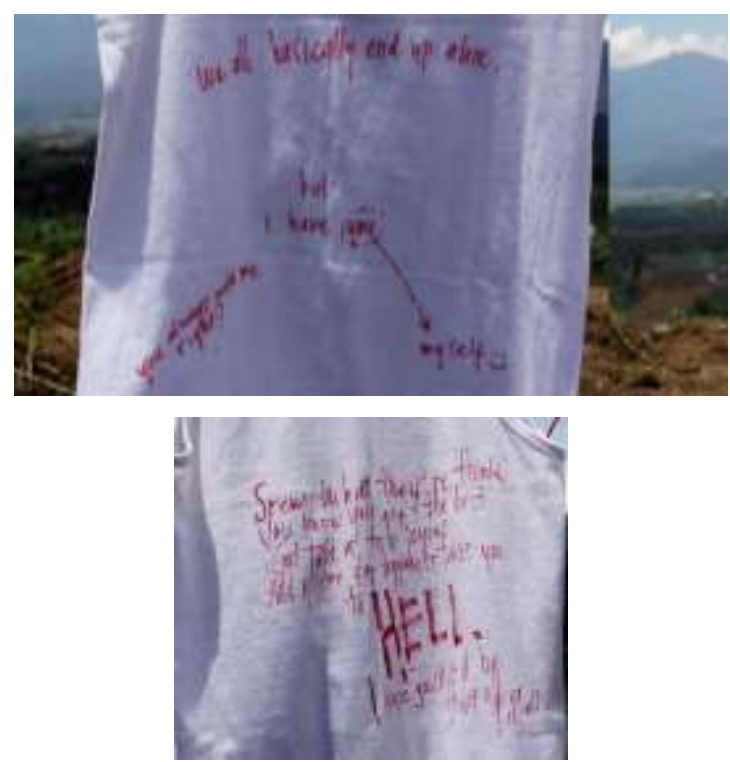

Source: Author.

Figure 39. The object of artwork is a cloth with the picture Eros - Psyche.

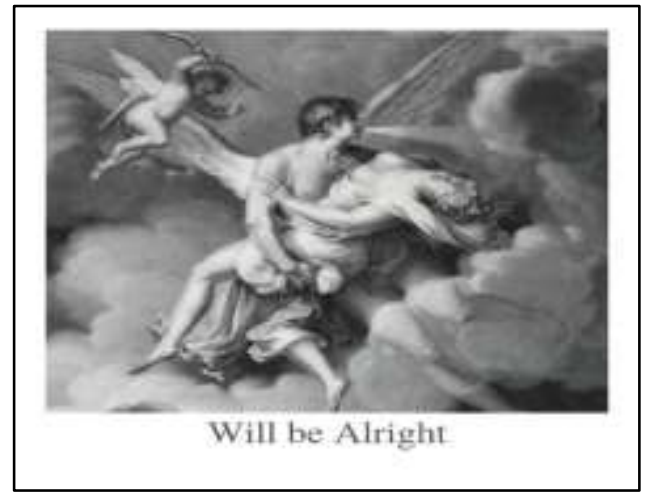

Source: Author.

\section{The Analysis of Previous Work}

Apart from discussing theories, there is also a discussion in terms of previous artworks that underlies the creation. Previous works that contributed to this creation were Julian Rosefeldt (Manifesto), Gerda Wegener (Solitaire), Mella Jaarsma (Cut Time) and Halsey (Manic Album).

\section{Julian Rosefeldt (Manifesto)}

Julian Rosefeldt is an artist from Berlin who often combines film and installation art. Rosefeldt's art ranges from documentary style to theatrical narrative. The work entitled Manifesto is 13-channel film installation created by Rosefeldt in 2015. Manifesto is a form of glorification for the tradition and literary beauty of the artists' manifesto. An artist's manifesto is expression of an individual or group of artists describing the motivations and intentions.

The media used by Rosefeldt inspire the current creation. The use of video projector media is the right choice to pack a the experience with a plot. It is supported by other mixed media installations will provide complexity to the appreciation of the art. 
One of the media that composes work installation entitled "Lie" "To be God" and "To be Human" uses video projector to build an atmosphere and provide a metaphor of the experience of sexuality in art. The work entitled "Lie" presents a metaphorical experience of sexuality about abortion through stop motion video display from projector. Meanwhile, the art entitled "To be God" and "To be Human" use video projectors as an atmosphere builder. The atmosphere development in "to be Human" is visually influenced by one of the media that composed by Julian Rosefeldt's work in Manifesto.

Figure 40. Projector video of “to be human".
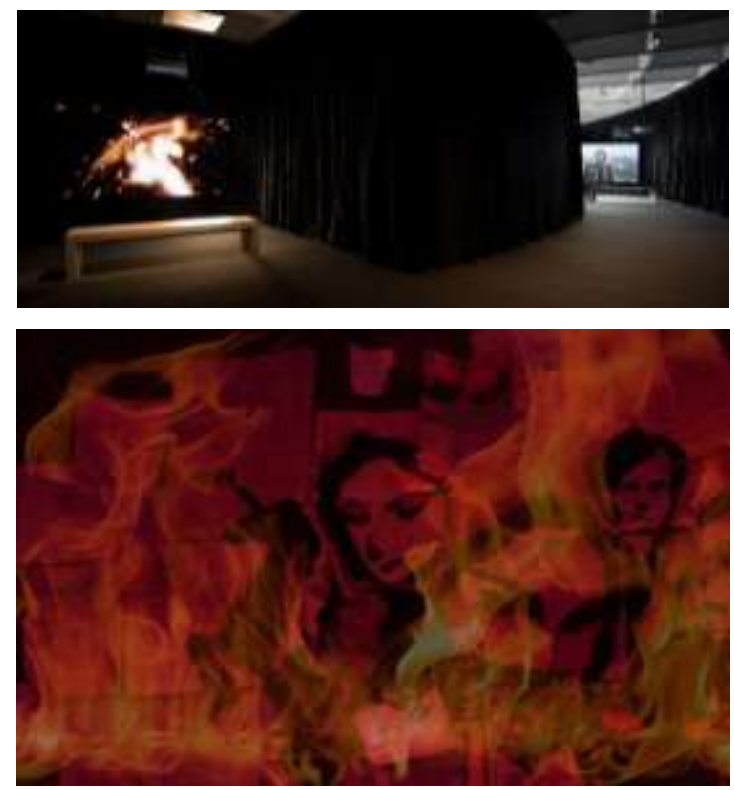

Source: Author.

\section{Gerda Wegener (Solitaire)}

Gerda Marie Fredrikke Gottlieb a.k.a Gerda Wegener is a Danish painter known for his erotica and art deco styles in his work. The name Wegener comes from the name of her ex-husband Einar Magnus Andreas Wegener, who is the world's first transgender and artist, (Meyer, 2011).

In the mid-19th century, Gerda asked her ex-husband to pose for a painting with the concept of woman in a yellow dress. Because of this incident, Einar's "Lili Elbe" was born, A few years later Lili decided to undergo experimental sex reassignment surgery and become the world's first transgender. Meanwhile, Gerda's works on Lili are the first works to communicate LGBTQ+ ideas as the topic of sexuality. 
Figure 41. Color and the object of "to be God" was influenced by Gerda's artwork.

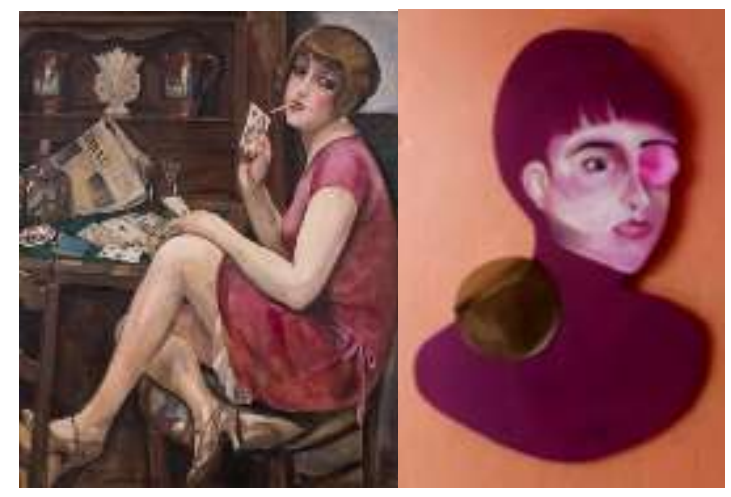

Source: Author.

\section{Mella Jaarsma (Potong Waktu)}

Mella Jaarsma is a Dutch-born artist who has career and stay in Indonesia. Jaarsma has lived in Yogyakarta since 1984. Jaarsma focuses on the cultural and racial diversity that inherent in human body. She presents something that complements and covers the body (inside and outside) as part of an art. Therefore his artworks called as costume installations.

Human body as the object of the installation inspires the current creation of installation art. Sexuality closely related to the body because it discusses what is inside humans. Especially in Jaarsma's work entitled Potong Waktu. Both the construction and the existence of human body influence the creation of art.

Figure 42. The existence of human body as part of artwork and the construction pattern of the installation that influenced by Mella Jaarsma's (Potong Waktu).
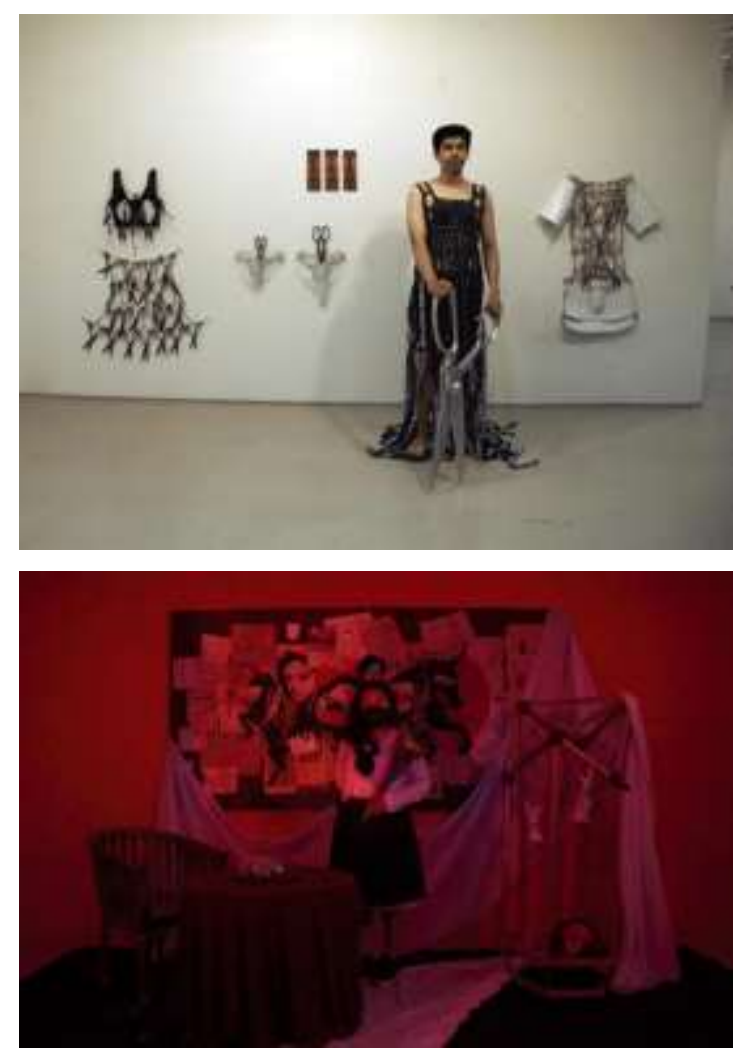

Source: Author. 


\section{Halsey (Album Manic)}

Ashley Nicolette Frangipane or professionally known as Halsey is an American singer, songwriter and visual artist. In early 2020, Halsey released a new album entitled Manic. Manic is an episode of bipolar condition that causes a person to feel both sad and overly happy.

The way Halsey delivers stories into music albums, inspires the creation of 6 types of audio stories within the concept of sexuality experience and education. Besides the audio, there is also Manic Lyric Audio from Manic album which displays a visual metaphor story of each single in the album. The visual metaphor was packaged in form of stop motion with storyline according based on the concept. The stop motion inspired the creation of a similar work in an audiovisual installation entitled "Lie".

\section{The finding of Creation Process}

After a long process in creation, there were several discoveries outside the concept. Especially at the stages of Elaboration and Refinement and Execution in a Medium.

At the Elaboration and Refinement and Execution in a Medium stages there are several objects that suddenly appear in sketch.

The appearance of these objects is basically a human creative impulse during the art creation. Even though the concept has been completely written, the brain still produces plans that related directly or indirectly to the artwork creation.

Not only objects, the color selection in this audiovisual installation art is the result of human creative impulses. This creative impulse is built from previous experiences which then stored consciously and unconsciously in human memory. Finally, at the moment of the creative process, the memory will come out and contribute as the results of the process.

Therefore it requires mastery of theory and references of previous works to stimulate creative impulses

\section{Conclusion}

Bsed on the result and discussion, it can be concluded that: The creation of audiovisual installations with the idea of experiences and effective sexuality education influenced by Laura $\mathrm{H}$. Chapman method. Although this method was coined in 1978, the presented steps presented did not hinder the process of creation and still relevant to the current creation.

After going through the Inception of Idea, Elaboration and Refinement, and Execution in a Medium, there are findings that affect the results of audiovisual installation art. These findings include the addition of previous unplanned objects and colors. This is an impulse creative impulse of art creation. Every turning point in creation of art is certain and normal because of the existence of human creative impulses.

After the long process of art creation, it is suggested to make special research that related to the presentation and utilization of installation art. Therefore audiovisual installation can be practically useful in field of education.

\section{References}

ART TERM. (2020). Installation Art. Tate Galleries. https://www.tate.org.uk/art/art-terms/i/installation-art

Berger, K. S. (2019). Developing Person Through Childhood and Adolescence.

Bressler, C. E. (2011). Literary Criticism: An Introduction to Theory and Practice (A Second Printing), (5th ed.).

Chapman, L. H. (1978). Approaches to art in education. Harcourt College Pub.

Code, L. (2000). Encyclopedia of Feminist Theories. Routledge.

Damayanti, M., Anni, C. T., \& Heru Mugiarso. (2018). Layanan Informasi dengan Media gambar untuk meningkatkan pemahaman sex education siswa. Indonesian Journal of Guidance and Counseling: Theory and Application, 7(1). file:///C:/Users/mitra/Downloads/17879-Article Text-48434-1-10-20180504 
Research, Society and Development, v. 10, n. 6, e39610615627, 2021

(CC BY 4.0) | ISSN 2525-3409 | DOI: http://dx.doi.org/10.33448/rsd-v10i6.15627

(1).pdf

Eyo, E., \& Ibanga, D. A. (2017). A colloquy on violence and non-violence: towards a complementary conflict resolution. American Journal of Social Issues and Humanities, 7(2), 137-150.

Ferriani, B. (2013). Ephemeral Monuments - History and Conservation of Installation Art. Getty Publications.

Finley, L. (2018). Acquaintance rape. In M. D. Smith (Ed.), Encyclopedia of Rape and Sexual Violence (p. 1). ABC-CLIO.

Jackson, M. J. (2010). The Experimental Group: Ilya Kabakov, Moscow Conceptualism, Soviet Avant-Gardes. University of Chicago Press.

Komnas Perempuan. (2019). Korban Bersuara, Data Bicara, Sahkan RUU Penghapusan Kekerasan Seksual Sebagai Wujud Komitmen Negara. In CATAHU 2019

McConchie, J., \& Rolfe, M. (2016). Ephemeral Monuments: History and Conservation of Installation Art. Journal of the Institute of Conservation, 39(1), 7072. https://doi.org/10.1080/19455224.2015.1104142

Meyer, S. (2011). Mit dem Puppenwagen in die normative Weiblichkeit.Lili Elbe und die journalistische Inszenierung von Transsexualität in Dänemark. NORDEUROPAforum - Zeitschrift Für Kulturstudien, 20(1), 33-61. https://doi.org/10.18452/8038

Policy Brief. (2016). Sexuality education - what is it? Sex Education, 16(4), 427-431. https://doi.org/10.1080/14681811.2015.1100599

Richardson, J., Gorbman, C., \& Vernallis, C. (2013). The Oxford Handbook of New Audiovisual Aesthetics. https://doi.org/10.18452/8038

Schiavoni, G. (2016). Il matriarcato. Ricerca sulla ginecocrazia nel mondo antico nei suoi aspetti religiosi e giuridici. Einaudi.

Schleicher, A. (2015). PISA Results in Focus. In International Student Assessment. OECD.

Storkey, E. (2020). Women in a Patriarchal World; Twenty five empowering stories from the Bible. SPCK Publishing.

Ubell, R. M. L., \& Randall, M. (2018). Myths and Misogyny: The Legal Response to Sexual Assault. University of Western Ontario.

UNESCO. (2018). International technical guidance on sexuality education An evidence informed approach. 